\title{
Symptomatic spinal extradural arachnoid cyst with cord compression in a family: case report
}

\author{
Arnold H. Menezes, MD, ${ }^{1,2}$ Patrick W. Hitchon, MD,1 and Brian J. Dlouhy, MD ${ }^{1,2}$ \\ 1Department of Neurosurgery and 2Division of Pediatric Neurosurgery, University of lowa Hospitals and Clinics, lowa City, lowa \\ A family with familial spinal extradural arachnoid cyst is presented. A 14-year-old boy had an extensive T-8 through \\ L-2 dorsal extradural arachnoid cyst with spinal cord compression and slowly progressive myelopathy. His mother had \\ presented 4 years earlier with acute excruciating back pain due to the combination of a lumbar extradural arachnoid cyst \\ at L2-4 and an extruded disc at L3-4. The literature is reviewed in light of the pathogenesis, imaging, and surgical tech- \\ nique required for treatment.
}

https://thejns.org/doi/abs/10.3171/2017.3.SPINE17186

KEY WORDS extradural arachnoid cyst; spinal cord compression; paraparesis; congenital

$\mathrm{S}$ PINAL extradural arachnoid cysts are a rare cause of neurological deficit in the pediatric population., ${ }^{1,3,4,8}$, $9,12,13,16,25$ Depending on their location, they may cause myelopathy, radiculopathy, and focal pain, and may present either with a rapid evolving clinical picture or a gradually progressive deficit. A few of these cysts have been reported to be associated with a familial history of spinal extradural arachnoid cysts and fall in the category of Milroy's disease. ${ }^{2,5,21-23}$ This disease consists of a spinal extradural arachnoid cyst, familial lymphedema in the patient, history of bronchial asthma, and a double row of eyelashes. ${ }^{5} \mathrm{We}$ report the case of a 14-year-old boy with compressive thoracic myelopathy due to a dorsal extradural arachnoid cyst. His mother had previously undergone surgery for excision of a lumbar extradural arachnoid cyst. We reviewed the literature and present the recommendations.

\section{Case Reports}

Case 1: Son

This 14-year-old boy presented with back pain and difficulty walking of 2 months' duration. The patient had a history of having slipped on the floor and sustaining lower thoracic back pain, which slowly improved. It worsened again a few days later after he fell out of a chair. He had been active in football and other athletic activities, which provoked the pain. He had difficulty walking, with ab- normal sensation in the lower extremities that worsened with bending, and he noticed difficulty with emptying his bladder.

On examination, the patient weighed $115 \mathrm{~kg}$ and was 5 feet, 11 inches tall. He exhibited good strength in his lower extremities. The positive findings were decreased touch, pain, temperature, and vibration sensations below the T- 8 level. He had severe dysesthesias between T-8 and L-2 on the anterior abdomen and even worse dysesthesias on his back and upper thighs. He walked with a broad-based gait with small steps. The deep tendon reflexes were diminished. Romberg testing was positive, and he was unable to toe walk.

MRI revealed an extradural dorsal cystic lesion between T-7 and L-1 that extended into the neural foramina. The spinal cord was displaced ventrally. This lesion had a hyperintense signal on T2-weighted imaging (Fig. 1) and an isointense signal on T1-weighted imaging (Fig. 2) with epidural fat capping the lesion at T-7. There was scalloping of the posterior bony elements of the T-9, T-10, and T-11 vertebrae (Fig. 3).

At surgery, the patient underwent T8-L2 osteoplastic laminectomies, which revealed a dorsal, extradural, bluishwhite cystic lesion extending from T-8 to L-2 with a fistulous connection to the dural sac at several levels (Fig. 4A). These connections were sectioned between vascular clips 


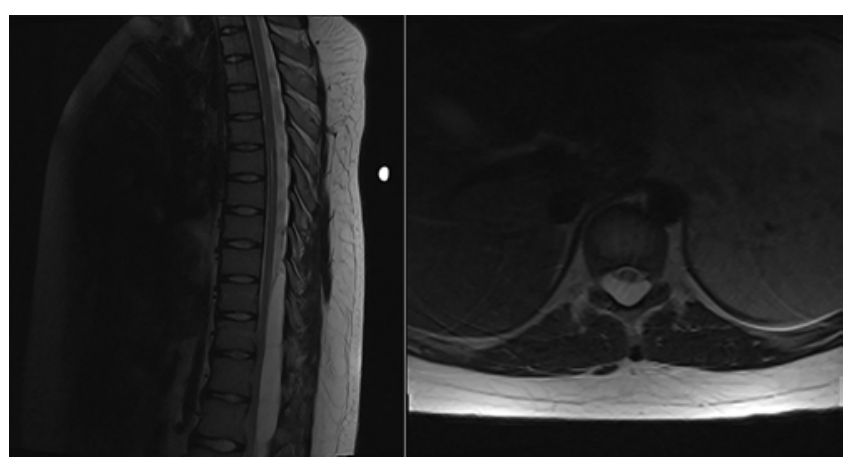

FIG. 1. Case 1. Left: Midsagittal T2-weighted MR image of the thoracic spine, revealing a dorsal extradural cyst at the T-8 level downward. Right: Axial T2-weighted MR image obtained at the T-10 level. The cystic mass displaces the spinal cord ventrally.

(Fig. 4B-D). At the L-1 level, the connection was significant, and the fistulous connection to the dura was suture ligated. The dura was covered with a thin strip of compressed flattened paraspinal muscle, fibrin glue, and $\mathrm{Du}-$ repair (Medtronic). The somatosensory evoked responses and motor evoked potentials were stable throughout the operative procedure. The entire cystic mass was removed. A spinal reconstruction of the dorsal bony elements was then made using titanium plates and screws.

At the 3-month follow-up, the patient exhibited complete recovery. MRI showed no evidence of cyst recurrence (Fig. 5). The pathological investigation of the cystic mass revealed that the cyst wall was composed of delicate fibrous connective tissue and was lined with meningoepithelial cells consistent with an arachnoid cyst.

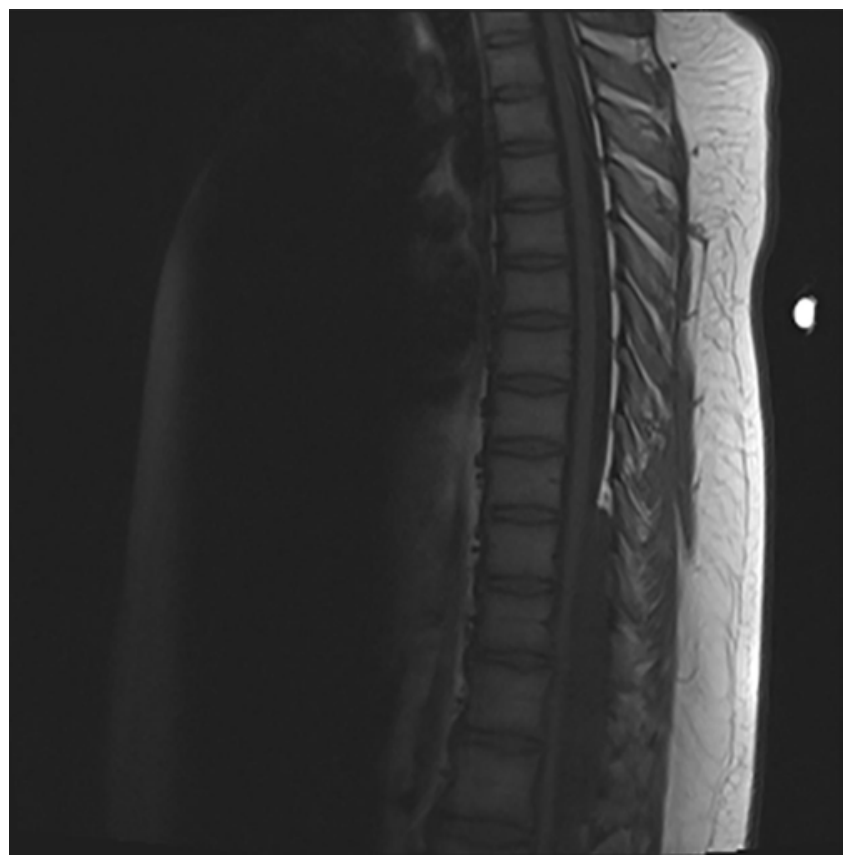

FIG. 2. Case 1. Midsagittal T1-weighted MR image of the thoracic cord. Note the epidural fat cap over the dorsal (hypointense) mass at the T-8 level.
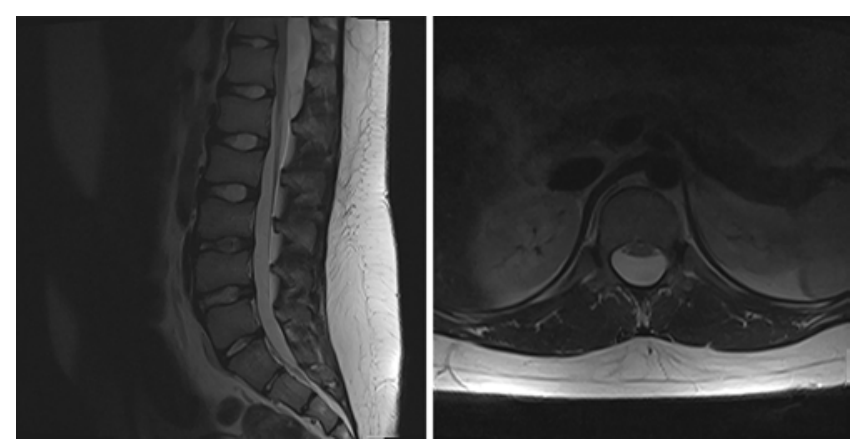

FIG. 3. Case 1. Left: Midsagittal T2-weighted MR image of the lumbar spine. The extradural cystic mass ends at the L1-2 level. Right: Axial T2-weighted MR image at L-1. The extradural arachnoid cyst displaces the spinal cord ventrally.

\section{Case 2: Mother}

This patient is the mother of the patient in Case 1. She presented to the neurosurgery service in 2010 at the age of 34 years. The presenting symptoms were back and left leg pain of 3 weeks' duration. The onset was abrupt and was described as being incapacitating. The pain was constant and worsened with activity. On physical examination, the main positive findings were weakness in the left iliopsoas and left quadriceps muscles. The patient had decreased pain sensation in the left lateral calf and foot, and the left ankle and knee reflexes were absent.

MRI of the thoracolumbar spine revealed a dorsal cystic extradural mass extending from the L-2 to L-4 vertebral bodies, mainly on the left. In association, a herniated intervertebral disc was visualized and was thought to be extruded at L3-4 on the left (Fig. 6). The extradural cystic mass had an epidural fat cap at L-1 dorsally. It was thought that this patient had 2 pathological processes: the extradural dorsal cystic mass and the extruded intervertebral disc at L3-4.

The patient underwent L2-4 osteoplastic laminectomies. A dorsal extradural cystic mass was encountered, from which clear fluid was aspirated between L-2 and L-4 (Fig. 7A). The cyst entered the neural foramen at L2 -3 and L3-4 on the left (Fig. 7B). The dural fistula was seen at L3-4 on the left and was thought to be approximately 8 $\mathrm{mm}$ in diameter. The fistula was closed primarily and suture ligated, and the cyst was removed (Fig. 7C). The L3-4 extraligamentous extruded intervertebral disc on the left was excised. The dura was coated with glue and the bony elements of the spine were reconstructed.

The pathological diagnosis was arachnoid cyst. The patient had a complete neurological recovery. Postoperative MRI showed no evidence of recurrence.

\section{Discussion}

Spinal extradural arachnoid cysts are very rare. When present, they are most commonly seen in the thoracic spinal canal, followed by the lumbar and then the cervical spinal canals.11,12,17,19,20,23 The majority of these cysts have an intradural arachnoid communication, which is either in the dorsal dura mater or at the dorsal root sleeve exit. $1,3,7,20$, ${ }^{23,25,28} \mathrm{~A}$ few have been reported as being noncommuni- 

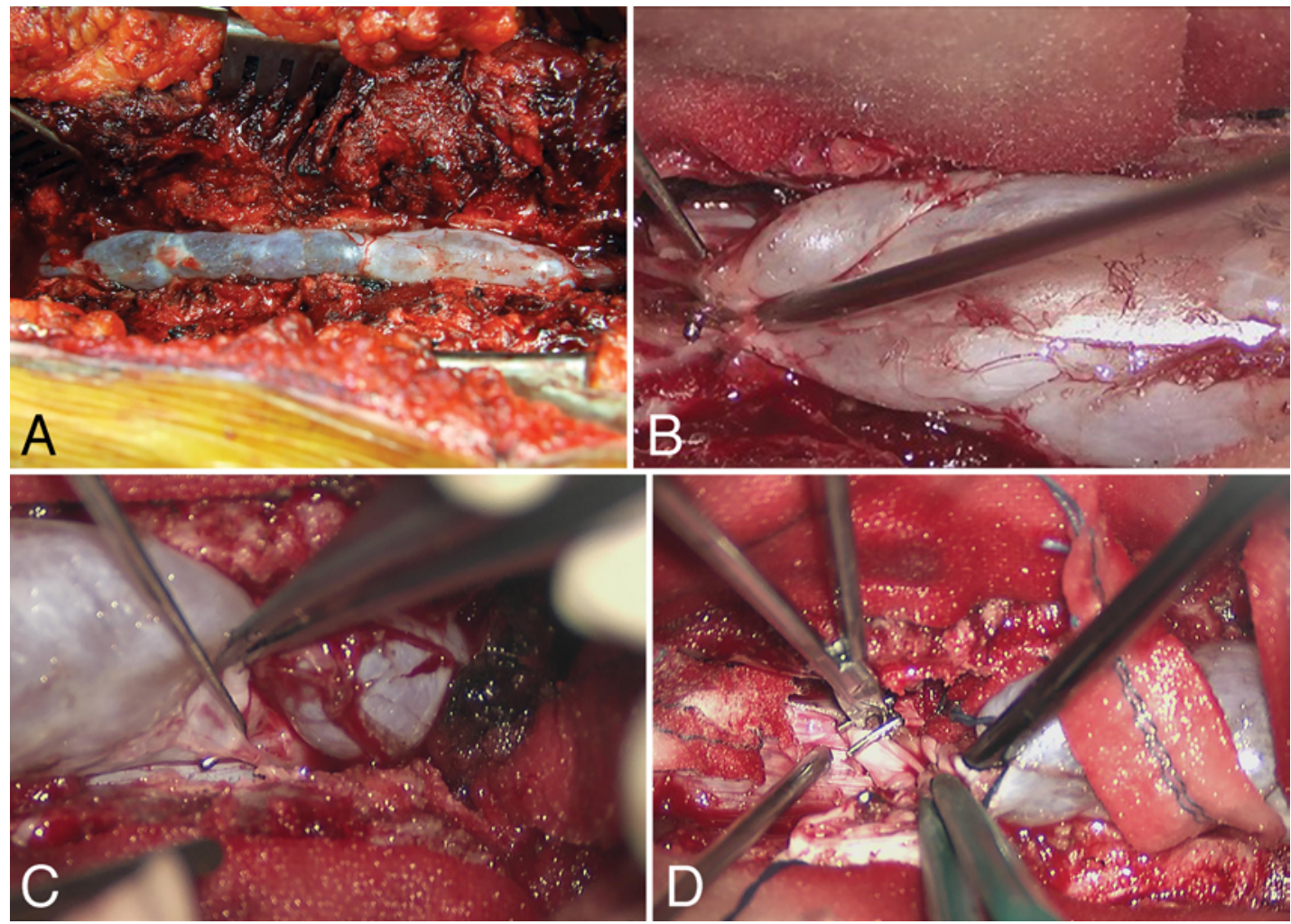

FIG. 4. Case 1. A: T8-L2 osteoplastic laminectomy exposing a bluish cystic mass (extradural arachnoid cyst). B: Intraoperative photograph demonstrating inferior fistulous connection of the dorsal extradural arachnoid cyst. C: Fistulous tract at superior extent of cystic mass. D: Tract of the lower level of the cyst, isolated, and sectioned from the dorsal extradural arachnoid cyst.

cating with the subarachnoid sac. ${ }^{14}$ It has been suggested that the initial arachnoid herniation enlarges due to pulse pressures within the cerebrospinal fluid, and the cyst subsequently becomes loculated due to failure of cyst empty-

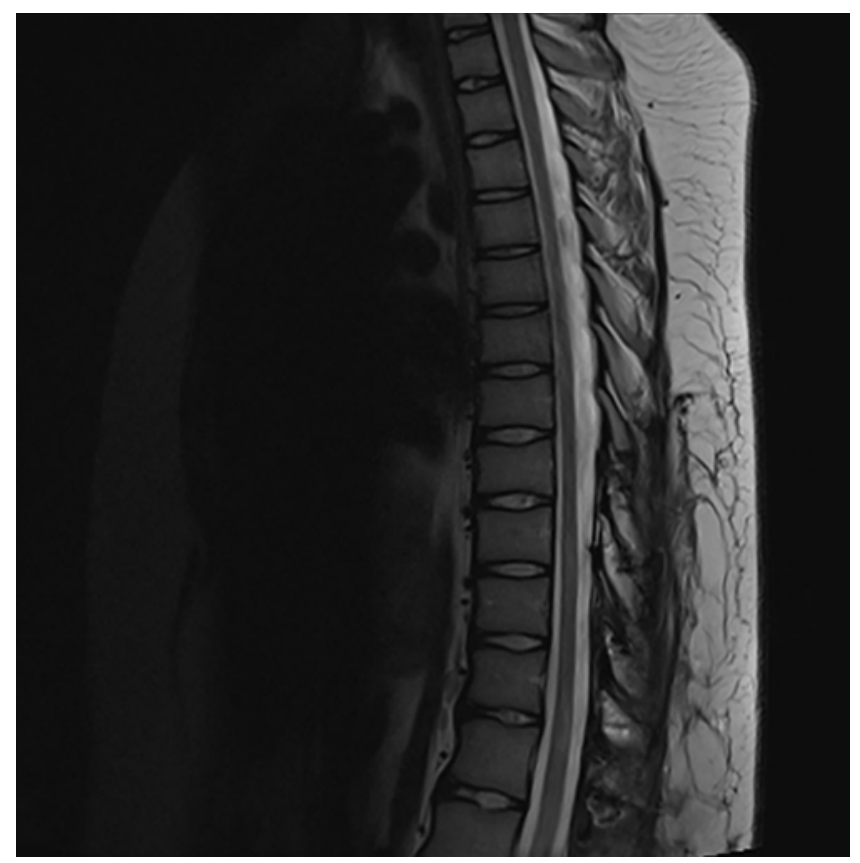

FIG. 5. Case 1. Midsagittal T2-weighted MR image of the thoracic spine obtained 3 months after surgery. There is no recurrence. ing. Multiple spinal extradural arachnoid cysts have been reported, which require extensive exposure., $13,17,29,30$

Spinal cord herniation and prolapsed nerve roots through the fistulous communication have been reported. ${ }^{3,15,18,27}$ MRI with thin cuts through the affected area has proved to be the best imaging modality for identification of the extradural cyst. Doita et al. ${ }^{6}$ used kinematic MRI in a thoracic spinal extradural arachnoid cyst. This was an attempt to explain the undulating exacerbation of symptoms. They demonstrated cyst-filling changes with Valsalva maneuvers using kinematic MRI. CT myelography with delayed scanning has also been used to visualize the

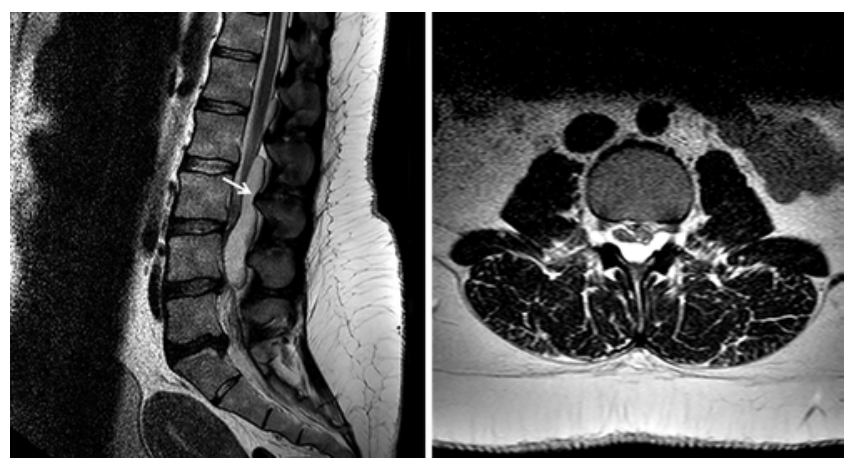

FIG. 6. Case 2. Left: Midsagittal lumbar T2-weighted MR image revealing an extradural dorsal cyst (arrow) and an extruded intervertebral disc at L-3. Right: Axial T2-weighted MR image at the L3-4 level demonstrating the dorsal cyst extending into the neural foramina. Note the extruded ventral disc. 

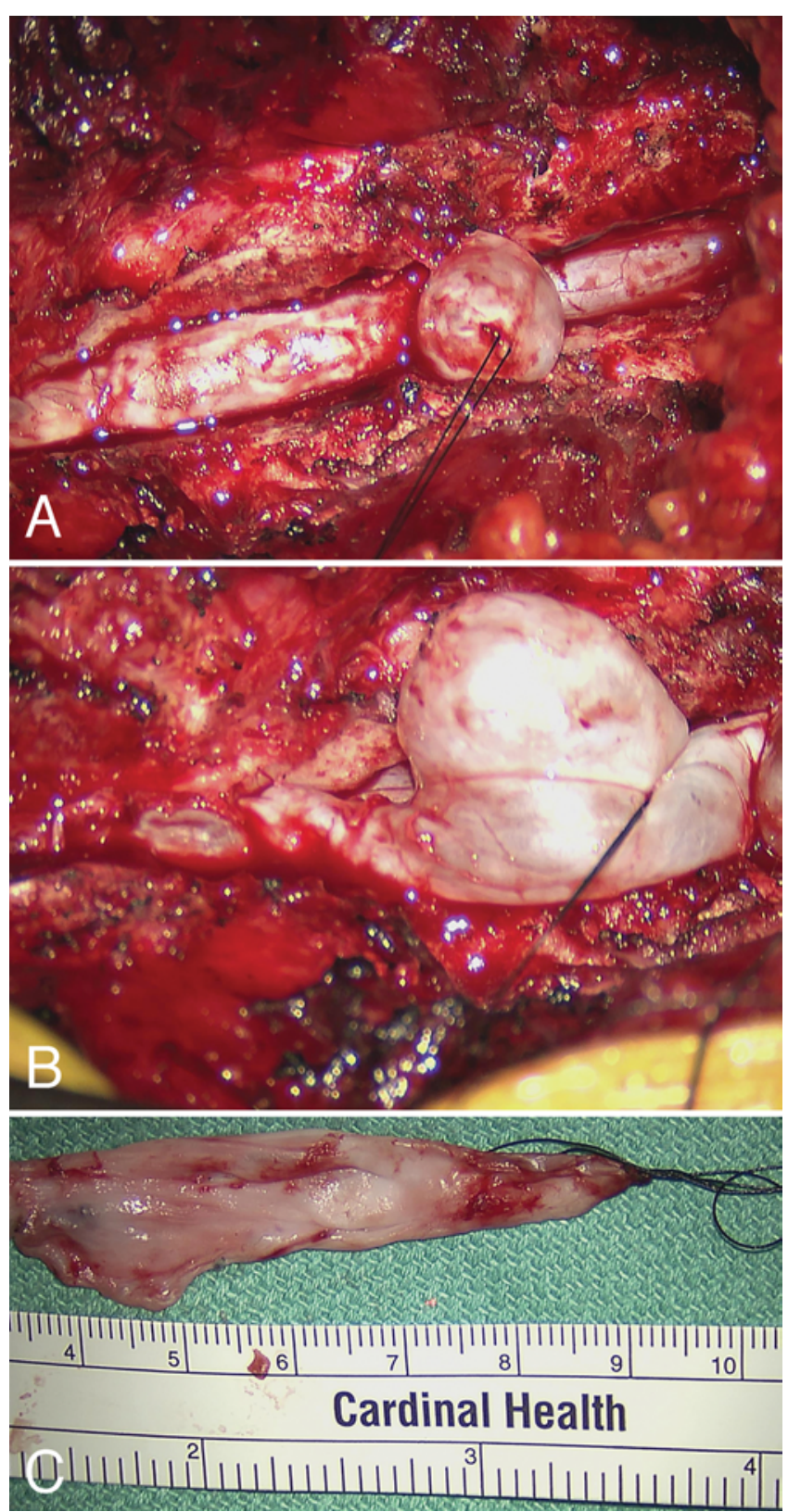

FIG. 7. Case 2. A: Operative photograph after L2-4 laminotomies. Note the dorsal extradural arachnoid cyst. B: Cystic mass extending into ventral foramen at L3-4. C: Excised extradural arachnoid cyst.

fistulous connection. ${ }^{3,4,13,27}$ In these case reports, the fistulous connection occurred at many levels, which makes it difficult to identify on preoperative imaging, as happened in our Case 1.

Ogura et al. studied patients with spinal extradural arachnoid cysts that consisted of 2 familial and 7 sporadic cases. ${ }^{22}$ Both familial cases were associated with lymphedema-distichiasis syndrome, whose causal gene is FOXC2. ${ }^{21,22}$ Sanchez-Carpintero et al. studied a complete family of 45 living members with lymphedema-distichiasis syndrome. ${ }^{26}$ Seven individuals had extradural arachnoid cysts and FOXC2 gene mutation. Bergland reported on a family with 3 children who had this syndrome and intraspinal extradural arachnoid cysts. ${ }^{2}$ However, no gene abnormalities were identified in the mother and son described in our report, and they did not fulfill the requirements for Milroy's disease..$^{2,5}$

Lee et al. analyzed 44 operations in a literature review of spinal extradural arachnoid cysts and added 8 of their own patients. ${ }^{11}$ The majority of lesions were in the thoracic spinal canal. Resection of the lesion with dural repair of the fistulous communication resulted in a long-term recurrence rate of $2 \%$. However, if the dural defect was not addressed, the recurrence rate was $66.7 \%$. Kerr et al. reported on a spinal extradural arachnoid cyst that occurred in a 14-year-old patient with recurrent abdominal pain and no neurological deficits. ${ }^{10}$ A large extradural arachnoid cyst was present between T-11 and L-2. The fistulous communication was at $\mathrm{T}-11$.

The extradural arachnoid cyst must be visualized in its entirety, and an attempt must be made to resect the lesion, with the aim of locating the fistulous communications. ${ }^{11-13,24}$ Large, spinal extradural arachnoid cysts have required extensive laminoplasty/laminectomies. In our 14-year-old patient, there were several areas of fistulous communication that had to be addressed. The surgical technique included clipping and ligation of the communications together with the laying of a thin compressed, flattened paraspinal muscle graft with fibrin glue over it.

Extensive laminectomies have been avoided with the use of en bloc laminoplasty with reconstruction using titanium plates and screws.

\section{Conclusions}

Spinal extradural arachnoid cysts are rare and mostly occur in the thoracic region, and they are found in children as well as in adults. Identification of the fistulous communication is critical for long-term resolution of symptoms.

\section{Acknowledgments}

We thank Mary Jo Piper for the manuscript preparation.

\section{References}

1. Bakhti S, Djaadi L, Terkmani F, Tighilt N, Djennas M: Extradural spinal arachnoid cyst occurring in a child: a case report. Turk Neurosurg 24:90-93, 2014

2. Bergland RM: Congenital intraspinal extradural cyst. Report of three cases in one family. J Neurosurg 28:495-499, 1968

3. Cho HY, Lee SH, Kim ES, Eoh W: Symptomatic large spinal extradural arachnoid cyst: a case report. Korean J Spine 12:217-220, 2015

4. Choi SW, Seong HY, Roh SW: Spinal extradural arachnoid cyst. J Korean Neurosurg Soc 54:355-358, 2013

5. Chynn KY: Congenital spinal extradural cyst in two siblings. Am J Roentgenol Radium Ther Nucl Med 101:204-215, 1967

6. Doita M, Nishida K, Miura J, Takada T, Kurosaka M, Fujii M: Kinematic magnetic resonance imaging of a thoracic spinal extradural arachnoid cyst: an alternative suggestion for exacerbation of symptoms during straining. Spine (Phila Pa 1976) 28:E229-E233, 2003

7. Ersahin Y, Yildizhan A, Seber N: Spinal extradural arachnoid cyst. Childs Nerv Syst 9:250-252, 1993

8. Jain F, Chaichana KL, McGirt MJ, Jallo GI: Neonatal ante- 
rior cervical arachnoid cyst: case report and review of the literature. Childs Nerv Syst 24:965-970, 2008

9. Kahraman S, Anik I, Gocmen S, Sirin S: Extradural giant multiloculated arachnoid cyst causing spinal cord compression in a child. J Spinal Cord Med 31:306-308, 2008

10. Kerr JM, Ukpeh H, Steinbok P: Spinal extradural arachnoid cyst presenting as recurrent abdominal pain. Childs Nerv Syst 31:965-969, 2015

11. Lee CH, Hyun SJ, Kim KJ, Jahng TA, Kim HJ: What is a reasonable surgical procedure for spinal extradural arachnoid cysts: is cyst removal mandatory? Eight consecutive cases and a review of the literature. Acta Neurochir (Wien) 154:1219-1227, 2012

12. Lee HJ, Cho DY: Symptomatic spinal intradural arachnoid cysts in the pediatric age group: description of three new cases and review of the literature. Pediatr Neurosurg 35:181-187, 2001

13. Liu JK, Cole CD, Kan P, Schmidt MH: Spinal extradural arachnoid cysts: clinical, radiological, and surgical features. Neurosurg Focus 22(2):E6, 2007

14. Liu JK, Cole CD, Sherr GT, Kestle JRW, Walker ML: Noncommunicating spinal extradural arachnoid cyst causing spinal cord compression in a child. J Neurosurg (Pediatrics 3) 103:266-269, 2005

15. Masuzawa H, Nakayama H, Shitara N, Suzuki T: Spinal cord herniation into a congenital extradural arachnoid cyst causing Brown-Séquard syndrome. Case report. J Neurosurg 55:983-986, 1981

16. McCrum C, Williams B: Spinal extradural arachnoid pouches. Report of two cases. J Neurosurg 57:849-852, 1982

17. Myles LM, Gupta N, Armstrong D, Rutka JT: Multiple extradural arachnoid cysts as a cause of spinal cord compression in a child. Case report. J Neurosurg 91 (1 Suppl):116-120, 1999

18. Nejat F, Cigarchi SZ, Kazmi SS: Posterior spinal cord herniation into an extradural thoracic arachnoid cyst: surgical treatment. J Neurosurg 104 (3 Suppl Pediatrics) 104:210211,2006

19. Netra R, Min L, Shao Hui M, Wang JC, Bin Y, Ming Z: Spinal extradural meningeal cysts: an MRI evaluation of a case series and literature review. J Spinal Disord Tech 24:132136,2011

20. Novak L, Dobai J, Nemeth T, Fekete M, Prinzinger A, Csecsei GI: Spinal extradural arachnoid cyst causing cord compression in a 15-year-old girl: a case report. Zentralbl Neurochir 66:43-46, 2005

21. Ogura Y, Fujibayashi S, Iida A, Kou I, Nakajima M, Okada E, et al: A novel FOXC2 mutation in spinal extradural arachnoid cyst. Hum Genome Var 2:15032, 2015
22. Ogura Y, Yabuki S, Iida A, Kou I, Nakajima M, Kano H, et al: FOXC2 mutations in familial and sporadic spinal extradural arachnoid cyst. PLoS One 8:e80548, 2013

23. Oh JK, Lee DY, Kim TY, Yi S, Ha Y, Kim KN, et al: Thoracolumbar extradural arachnoid cysts: a study of 14 consecutive cases. Acta Neurochir (Wien) 154:341-348, 2012

24. Payer M, Brühlhart K: Spinal extradural arachnoid cyst: review of surgical techniques. J Clin Neurosci 18:559-560, 2011

25. Rahimizadeh A, Kaghazchi M, Shariati M, Abdolkhani E, Abbasnejad E, Rahimizadeh S: Spinal extradural arachnoid cysts. Coluna/Columna 12:112-118, 2013

26. Sánchez-Carpintero R, Dominguez P, Núñez MT, PatiñoGarcía A: Spinal extradural arachnoid cysts in lymphedemadistichiasis syndrome. Genet Med 12:532-535, 2010

27. Sangala JR, Uribe JS, Park P, Martinez C, Vale FL: Nerve root prolapse into a spinal arachnoid cyst--an unusual cause of radiculopathy. Clin Neurol Neurosurg 111:460-464, 2009

28. Stechison MT, Hendrick EB, Cohen E: Spinal extradural arachnoid cyst. Pediatr Neurosci 15:36-38, 1989

29. Suryaningtyas W, Arifin M: Multiple spinal extradural arachnoid cysts occurring in a child. Case report. J Neurosurg 106 (2 Suppl):158-161, 2007

30. Takagaki T, Nomura T, Toh E, Watanabe M, Mochida J: Multiple extradural arachnoid cysts at the spinal cord and cauda equina levels in the young. Spinal Cord 44:59-62, 2006

\section{Disclosures}

The authors report no conflict of interest concerning the materials or methods used in this study or the findings specified in this paper.

\section{Author Contributions}

Conception and design: Menezes. Acquisition of data: Menezes. Drafting the article: Menezes. Critically revising the article: all authors. Reviewed submitted version of manuscript: all authors. Approved the final version of the manuscript on behalf of all authors: Menezes.

\section{Correspondence}

Arnold H. Menezes, Department of Neurosurgery, University of Iowa Hospitals \& Clinics, 200 Hawkins Dr., 1824 JPP, Iowa City, IA 52242.email: arnold-menezes@uiowa.edu. 